University of South Carolina

Scholar Commons

2012

\title{
Investigation of Carbon Corrosion Resistance of CNT Containing Electrode
}

\author{
Diana Larrabee \\ William A. Rigdon \\ University of South Carolina - Columbia, rigdonwa@email.sc.edu \\ Eli McPherson \\ Joshua Sightler \\ Xinyu Huang \\ University of South Carolina - Columbia, xyhuang@sc.edu
}

Follow this and additional works at: https://scholarcommons.sc.edu/eche_facpub

Part of the Biomechanical Engineering Commons, and the Catalysis and Reaction Engineering Commons

\section{Publication Info}

Postprint version. Published in ECS Meeting Abstracts, 2012, pages 1412-1412.

(C) ECS Meeting Abstracts, 2012, The Electrochemical Society Larrabee, D., Rigdon, W.A., McPherson, E., Sightler, J.J., Huang, X. (2012). Investigation of Carbon Corrosion Resistance of CNT Containing Electrode. ECS Meeting Abstracts, 1412-1412.

This Article is brought to you by the Chemical Engineering, Department of at Scholar Commons. It has been accepted for inclusion in Faculty Publications by an authorized administrator of Scholar Commons. For more information, please contact digres@mailbox.sc.edu. 


\section{Investigation of Carbon Corrosion Resistance of CNT Containing Electrode}

Diana Larrabee, William A. Rigdon, Eli McPherson, Joshua J. Sightler, Xinyu Huang

University of South Carolina

Mechanical Engineering Dept.

541 Main St., Columbia, SC 29208

Carbon support corrosion is one of the major degradation mechanisms of polymer electrolyte membrane (PEM) fuel cell. Carbon oxidation occurs in PEM electrode and is accelerated at high potential created by adverse operating conditions and improper distribution of reactants and products [1, 2, 3]. Carbon corrosion can lead to the thinning of the electrode layer and severe performance degradation. The detailed mechanisms of carbon support corrosion induced performance loss are still not fully understood; it is believed that the following events contribute to the decay: (1) structural collapse of the porous electrode due to the loss of carbon; (2) carbon surface modification due to the formation of hydrophilic surface groups which can induce water accumulation and flooding of the electrode; (3) detachment and dissolution of platinum, which results in the reduction of platinum surface area. Together, these processes contribute to the loss of electrode performance.

Carbon nanotubes (CNT) have been used as alternative Pt catalyst support, it has been reported that CNT support offers better resistance to carbon corrosion [4]. This can be partly attributed to the high intrinsic stability of CNT in comparison with carbon black (CB). In addition, CNT-containing electrode is more structurally robust, because CNT can reinforce the electrode layer to avoid and delay the collapse of electrode structure. To help elucidate the mechanisms for the improved carbon corrosion resistance of CNT-containing electrode, three types of electrodes were prepared: (1) Pt catalyst supported on carbon black from Tanaka Kikinzoku Kogyo (TKK), (2) Pt catalyst supported on the CNT, (3) A mixture of Pt catalysts supported CB and supported on CNT. The cathodes were subjected to an accelerated catalyst support corrosion test protocol. Periodic performance and electrochemical diagnostic tests were conducted to track the decay behavior. The initial test results are shown in Figure 1-4, the decay rate of the electrode with mixed $\mathrm{Pt} / \mathrm{CB}$ and $\mathrm{Pt} / \mathrm{CNT}$ is decreasing compared with that of Pt/CB electrode. These results will be compared with electrode with $\mathrm{Pt} / \mathrm{CNT}$ catalysts. Polarization was collected at $80^{\circ} \mathrm{C}, 85 \% \mathrm{RH}$, ambient pressure with $\mathrm{H}_{2} /$ Air on anode/cathode. The cyclic voltammetry was plotted at the same cell temperature and with a scan rate of $100 \mathrm{mV} / \mathrm{sec}$. The cell area was $25 \mathrm{~cm}^{2}$, and the anode was used as a reference.

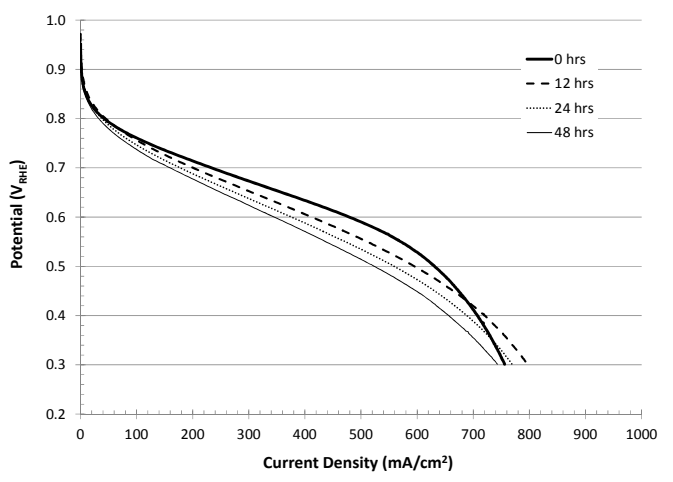

Figure 1. Performance decay with Pt/CB catalysts.

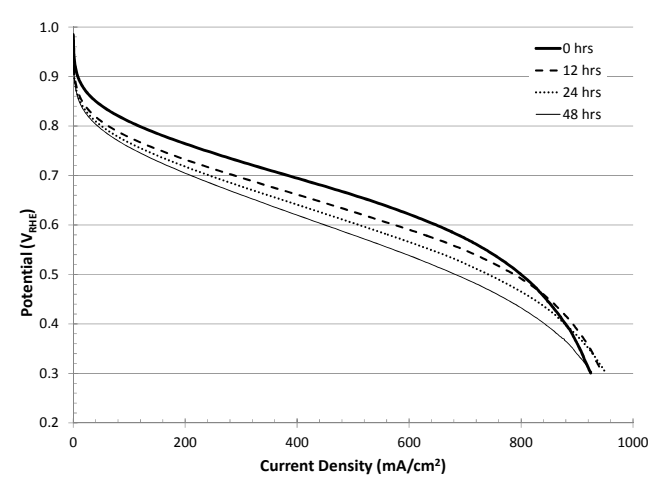

Figure 2. Performance decay with mixed Pt/CB and $\mathrm{Pt} / \mathrm{CNT}$ catalysts.

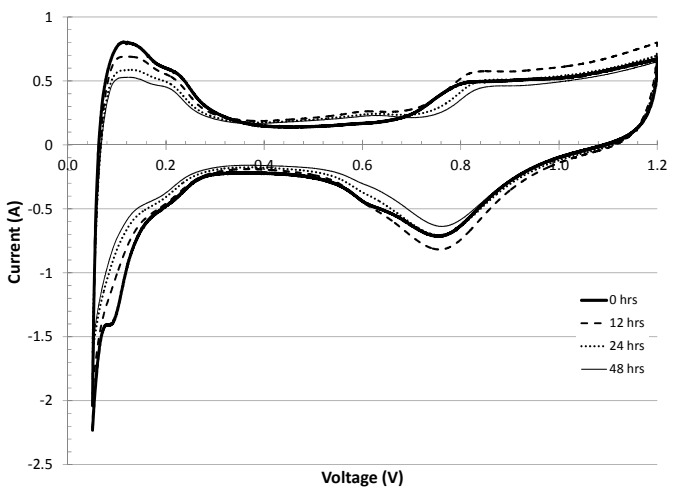

Figure 3. Change of ECA with Pt/CB catalysts.

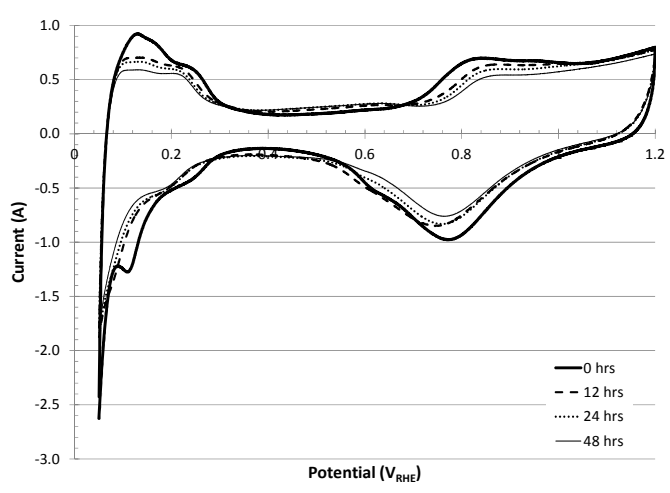

Figure 4. Change of ECA with mixed Pt/CB and Pt/CNT catalyst.

References:

[1] C.A. Reiser, L.Bregoli, T.W. Patterson, J.S. Yi, J.D. Yang, M.L. Perry, and T.D. Jarvi. A Reverse-Current Decay Mechanism for Fuel Cells. Electrochemical and Solid-State Letters. 8 (6), A273-A276. 2005.

[2] H. Tang, Z. Qi, M. Ramani, J.F. Elter. PEM fuel cell cathode carbon corrosion due to the formation of air/fuel boundary at the anode. Journal of Power Sources. 158, 1306-1312, 2006.

[3] R. Borup et al. Scientific Aspects of Polymer Electrolyte Fuel Cell Durability and Degradation. Chemical Reviews. Vol. 107, No. 10, 3937-3940. 2007.

[4] Y. Shao, G. Yin, Y. Gao, P.Shi. Durability Study of Pt/C and $\mathrm{Pt} / \mathrm{CNTs}$ Catalysts under Simulated PEM fuel Cell Conditions. Journal of Electrochemical Society. 153 (6), A1093-A1097. 2006. 